\title{
Resilience of soil nematodes to logging residue inputs following clear-cutting is site-dependent: a case study in rubber plantations on the Ivory Coast
}

KOUAKOU Kouakou Aymard ( $\square$ aymard.kouakou@ird.fr)

University NANGUI ABROGOUA https://orcid.org/0000-0003-4582-3927

Jean Trap

Univ. Montpellier

Sidy Diakhaté

LMI IESOL \& ELISOL Environnement

Yeo Kolo

University NANGUI ABROGOUA

Thibaut Perron

Univ. Montpellier

Frédéric Gay

Univ. Montpellier

\section{Research Article}

Keywords: Logging residues, Legumes, Soil nematodes, Diachronic monitoring, Resilience

Posted Date: February 18th, 2022

DOI: https://doi.org/10.21203/rs.3.rs-1327406/v1

License: () (1) This work is licensed under a Creative Commons Attribution 4.0 International License.

Read Full License 


\section{Abstract}

Aims The effect of tree plantations on soil biological functions when they replace tropical forests is detrimental. However, the current trend is to repeat tree plantations on the same land after clear-cutting, with a probable strong disturbance of soil functions. We addressed this question in rubber plantations, one of the world's most important tropical perennial crops, using soil nematode communities as an indicator of soil functioning. We hypothesised that (i) the restitution of logging residues from previous plantations will foster the resilience of the soil nematode community and (ii) this resilience will depend on soil type.

Methods An experimental design with different levels of logging residues for the previous rubber plantation and legumes (Pueraria phaseoloides) was set up in two rubber plantations on the lvory Coast with contrasting soil types. The response of nematodes to clear-cutting was monitored every 6 months over 24 months.

Results At both sites, we observed significant decreases in nematode abundance, diversity, taxonomic composition, and ecological nematode index six months after rubber tree logging. At the clay site, practices with logging residues led to higher resilience of the total nematode abundance. The ecological indices (enrichment index) in the sandy site were more resilient with logging residue input than without over time.

Conclusions Logging residues and legumes input was the most efficient practice for promoting soil nematode biodiversity and mitigating the negative impact of clear-cutting in rubber monocultures after a 40-year rotation. However, soil type determined both the level of resistance and resilience of the nematode community.

\section{Introduction}

Soil organisms are highly diverse and play crucial roles in providing large-scale ecosystem functions. Soil nematodes are responsible for key processes, such as nutrient cycling and organic matter transformation (Neher 2001; Irshad et al. 2011; Trap et al. 2016), among the soil ecosystem. In addition, they play a central role in regulating the structure and function of the food web in the soil, which is important for regulating multiple ecosystem functions (Baijing et al. 2019; Delgado-Baquerizo et al. 2020). Soil nematodes are good bioindicators sensitive to anthropogenic disturbance, such as acidification, pollution, biocides, fertilisation, and liming (Liu et al. 2016; Cortois et al. 2017; Pothula et al. 2019 ;Puissant et al. 2021). Many studies have found that nematodes are useful biological indicators of soil health after perturbation (Yeates 2003; Li et al. 2020) and that their beneficial effects on plants are highly affected by land management (Trap et al. 2021). Despite their importance in soil functioning, ecological studies on nematode resistance and resilience in agricultural systems following perturbations are lacking.

The global area of rubber plantations (RP, Hevea brasiliensis) has increased 1.9-fold over the last three decades, reaching 12.3 million ha in 2018 (FAO 2021). In the Ivory Coast, during this period, the area of 
RP increased 9.9-fold (FAO 2021), making the Ivory Coast the largest rubber producer in Africa and the fourth-largest in the world (APROMAC 2021). This rapid expansion of RP, mostly at the origin of the expansion of natural forests, has had negative environmental impacts on soil functions, such as soil erosion and acidification (Liu et al. 2015), and decreased soil carbon sequestration and fertility (Liu et al. 2019). Intensive rubber monocultures also threaten soil biodiversity (Xiao et al. 2014). Previous ecological studies have shown that the conversion of primary and secondary tropical forests to RP causes a significant loss and turnover of soil microorganisms (Lan et al. 2017; Singh et al. 2019), nematodes (Krashevska et al. 2019), and macrofaunal communities (Meng et al. 2012; Franco et al. 2019; Tondoh et al. 2019). However, most studies on soil biodiversity have focused on the negative impact of forest conversion on RP. Nowadays, in most rubber-producing countries, such as Thailand or the Ivory Coast, the trend is to relieve the pressure on natural forests (Chambon et al. 2018) and repeat plantations on the same land after clear-cutting trees over successive cycles.

RP are widely used, with a plantation cycle of 25-40 years (Oku et al. 2012). After an RP cycle, the greatest risk of soil degradation occurs during the replanting period, which extends from the clear-cutting of an old plantation to the planting of young rubber trees. During this period, the soil is subject to numerous disturbances mainly related to the (1) opening up of the environment following clear-cutting, (2) export of organic matter with machines, and (3) practice of deep subsoiling by heavy machinery. These practices may directly or indirectly affect biodiversity and soil function delivery (Missanjo and Kamanga-Thole 2014).

Some agricultural practices are commonly used to mitigate soil degradation after one or more plantation cycles, such as the implementation of a cover crop in inter-rows at planting (Broughton 1976; Liu et al. 2018). Sowing cover crops, mostly legumes, can improve soil properties (physicochemical and biological), consequently leading to an improvement in soil functioning and crop yield in the tropics (Fageria et al. 2005; Snapp et al. 2005; Gao et al. 2017). (Perron et al. (2021b) suggested that a likely alternative to restoring soil functions is to leave logging residues in the plot, given the large amount of nutrients and carbon accumulated in these residues. Harvest residues play ecological roles that are important for maintaining plantation fertility in a variety of soil and climate systems, such as reducing chemical fertiliser use, enhancing soil carbon sequestration, promoting soil nitrogen cycling(Gale and Cambardella 2002; Arcand et al. 2014) and reducing or avoiding environmental pollution from burning (Ibrahim et al. 2015). The addition of harvest residues significantly improves the total abundance and species richness of nematodes, and enhances the nematode community structure (Liu et al. 2016). The positive impact of harvest residues on soil fauna resilience (Lassauce et al. 2012; Carron et al. 2015), soil nutrients, and organic carbon has been also demonstrated (Huang et al. 2013; Alam et al. 2018; Singh et al. 2019). Recently, Perron et al. (2021a) showed that logging residue input in the plot improves soil functioning resilience in RP 18 months after rubber tree logging. However, to date, the effect of logging residue restitution on soil nematodes in RP has not been addressed.

It has been shown that soil texture is a key factor driving nematode abundance on a global scale, with effects that greatly overwhelm those of climate (van den Hoogen et al. 2020). Soil texture has been 
recognised as a determinant factor of the structure of soil nematode communities at lower scales (Quénéhervé 1998; Fiscus and Neher 2022). Thus, it is highly probable that soil nematode resilience following crop residue application is dependent on the soil type (Quénéhervé 1998). To determine the importance of organic matter input and soil texture, we set up a field experiment after logging the previous old RP in two industrial RP on the Ivory Coast with contrasting soil types. In each RP, different types of logging residues and legumes were added after clear-cutting to determine their respective impacts on the resilience of soil nematode communities. We hypothesised that (i) the input of logging residues and legumes after clear-cutting will promote the resilience of soil nematode communities, and (ii) soil types will affect both the resistance and resilience level of the nematode community.

\section{Material And Methods}

Field characteristics

Our study was conducted at two sites with contrasting soil textures on the Ivory Coast to verify our hypotheses. In the first RP, situated in the Grand Bassam Department (latitude $5^{\circ} 12^{\prime} 13^{\prime \prime} \mathrm{N}$, longitude $3^{\circ} 44^{\prime} 07^{\prime \prime}$ W) with an area of 5503 ha (Fig. S1), the soil texture was sandy loam with $11 \%$ clay content. This RP belongs to "the Société Africaine de Plantations d'Hévéas" (SAPH). This site was coded "sandy site". In the second RP located in southwestern Ivory Coast (latitude $4^{\circ} 40^{\prime} 14^{\prime \prime} \mathrm{N}$, longitude $7^{\circ} 08^{\prime} 18^{\prime \prime} \mathrm{W}$ ), with an area of 16300 ha, the soil texture was loamy sand with $23 \%$ clay (Table S1). This RP belongs to "The Société des Caoutchoucs de Grand-Béréby" (SOGB). This site was coded "clay site". The two plantations were located in a tropical forest with a sub-equatorial climate. The two sites were characterised by a long rainy season from April to June, short dry season from July to August, short rainy season from September to October, and a long dry season from November to March. The annual rainfall varies between 1700 and $1900 \mathrm{~mm}$, and the annual temperature varies between 24 and $27^{\circ} \mathrm{C}$. The topography was more heterogeneous at the clay site, with slopes ranging from $5-25 \%$, whereas there was no slope at the sandy site $(<5 \%)$. However, acidic soils prevailed at both sites, with the soil $\mathrm{pH}$ ranging between 4 and 5 in the $0-10-\mathrm{cm}$ horizon.

Experimental design and practices description

We set up an experimental design after the cutting of the previous RP (38-40 years old) using bulldozers in November 2017. At both sites, the natural rainforest was the previous land-use type, and the logged stand consisted of the first cycle of rubber trees. From November 2017 to January 2018, the same experimental design was used at both sites. Our experimental design consisted of four practices replicated in four random blocks, that is, 16 elementary plots per site consisting of a gradient of crop residues (Fig. S2) as follows:

- ROLO: no residues $(\mathrm{R})$ or legumes $(\mathrm{L})$ are left in the plot.

- ROL1: presence of legumes (Pueraria phaseoloides) only in the plot. 
- R1L1: presence of legumes (Pueraria phaseoloides) and all parts of the tree (leaves, fine branches, and stumps), except for the trunk, in the plot.

- R2L1: presence of legumes (Pueraria phaseoloides) and all parts of the tree (leaves, fine branches, stumps, and trunk) in the plot.

The surface of each plot was $1540 \mathrm{~m}^{2}$ at the sandy site and $1600 \mathrm{~m}^{2}$ at the clay site. Logging residues were placed in the inter-rows. In February 2018, $10 \mathrm{~kg} \mathrm{ha}^{-1}$ of seeds of the legume Pueraria phaseoloides were sown by broadcasting. The $C$ stocks in logging residues amounted to 36 and $51 \mathrm{~kg} \mathrm{ha}^{-1}$ in R1L1 at the sandy and clay sites, respectively, and 97 and $245 \mathrm{~kg} \mathrm{ha}^{-1}$ in R2L1 at the sandy and clay sites, respectively.

Soil sampling

Soil samples were collected with a sampling cylinder from the inter-row at a depth of $10 \mathrm{~cm}$ at 10 different locations in each plot. Soil samples from each elementary plot were composited into a $250 \mathrm{~g}$ sample. To minimise the influence of climate, especially rainfall, sampling was conducted between October and April. These two periods corresponded to the end of the dry season and beginning of the wet season, respectively. Five sampling campaigns were conducted from October 2017 to October 2019. The first campaign was conducted before the logging of the old RP. Before rubber tree logging, one composite soil sample was collected from the four blocks at each site. The first soil sampling campaign permitted the assessment of the initial state of the soil before clear-cutting. Sampling was then conducted every six months to monitor the temporal shifts in the soil nematode communities in response to logging residue and legume application. (Fig. S3).

Characterisation of soil nematode communities

The modified Seinhort method (Seinhorst 1962) was used to extract nematodes from $150 \mathrm{~g}$ of fresh soil. The collected nematodes were counted under a binocular loupe at 40x magnification and then fixed in a mixture of formaldehyde and glycerol. A representative subsample was mounted on mass slides to identify nematode individuals at the family or genus level. Nematodes were classified into five trophic groups, namely bacterivores, fungivores, herbivores, omnivores, and predators, and into life-history groups from the "coloniser-persistent" scale (Bongers, 1990; Yeates et al. 1993).

We then computed the following indices: total nematode abundance, abundance of free-living taxa, abundance of trophic groups, Shannon diversity (Shannon 1948), Pielou evenness index (Pielou 1975), nematode channel ratio (NCR) (Yeates, 2003), and the maturity index (MI) (Bongers 1990). We also computed the enrichment index $(\mathrm{El})$, which reflects soil nutrient enrichment, and the structure index ( $\mathrm{SI})$, which reflects the soil food web complexity (Ferris et al., 2001).

Data analyses 
For statistical analysis, we performed a logarithmic transformation of the nematode abundance to normalise the data. Linear mixed-effects models (LMMs) were implemented to evaluate the effects of site, practice, sampling date, and their interactions on nematode parameters. The temporal changes in nematode abundance at each site were tested with LMMs, with the sampling date as a random factor and practices as a fixed factor. We performed the analysis using the R package ImerTest (Kuznetsova et al. 2017). Tukey's multiple comparisons were used to test the temporal changes within each practice in the case of ANOVA using the agricolae package (de Mendiburu 2020). We used an integrated approach, Hill numbers ${ }^{\mathrm{D} D}$ (Gotelli and Chao 2013), to characterise the taxonomic diversity profile of soil nematode communities (Chao et al. 2014). Hill's numbers combined the species richness and Shannon diversity index, and Simpson's measures were converted into a class of diversity measures. Hill numbers can be plotted as a function of $\mathrm{q}$ on a continuous graph, resulting in a pattern of diversity for the effective taxon richness. When species abundance was not considered, $q=0$, and we obtained ${ }^{0} D$, which corresponds to species richness. When $q=1$, we obtained the exponential form of Shannon's diversity index ${ }^{1} D$, which was interpreted as the number of species specific to the community or the number of identical species in the assemblage. When there were more dominant species than rare species in the habitat, $q=2$, and we obtained ${ }^{2} D$, which is the inverse of the Simpson's index. Thus, 2D can be described as the number of dominant or very abundant species within a community. To calculate the diversity profiles of nematode communities by sampling date and according to different practices, we used the entropart package (Marcon and Hérault 2015). We performed Tukey-corrected pairwise multiple comparisons to assess the differences in soil nematode diversity patterns between practices at each sampling date using the multicomp package (Hothorn et al. 2008). As the diversity and taxonomic composition may change under each practice on the sampling date, we performed non-metric multidimensional scaling (NMDS) to examine taxonomic community composition patterns. Both NMDS and PERMANOVA were performed for the soil nematode communities using the vegan package (Oksanen et al. 2019). To estimate the resilience of nematode communities between practices at each site across the sampling date of the old plantation (before logging), the beta diversity was computed using Sorensen's pairwise dissimilarity. Beta diversity can be divided into two components: turnover (replacement of species with new species) and nestedness (loss or gain of species between practices, Baselga, 2010). To determine whether differences in community composition were primarily due to species turnover or nestedness, we used the betapart package to partition beta diversity (Baselga et al. 2021). We calculated the ratio (nestedness/Sorensen) to determine whether the difference in the composition of nematodes was related to turnover or nestedness. If the ratio (nestedness/Sorensen) is $<0.5$, beta diversity is governed by nestedness; however, if this ratio is $>0.5$, the imbrication is responsible for the new community (Dobrovolski et al., 2012; Si et al., 2015). Linear mixed-effects models implemented using the ImerTest package in R (Kuznetsova et al. 2017) and Tukey's post hoc test were used to compare times and practices. RStudio version 1.3.1093 (RStudio Team 2020) was used for all statistical analyses.

\section{Results}


Within all the factors tested (sites, practices, times), the effect of "site" was the most significant (Table 1) for more than half of the nematofaunal parameters (i.e., total abundance, Shannon diversity, and taxon richness), particularly in terms of interactions with practices and/or times.

Table 1

Result of linear mixed effects models (LMMs) $P$ values for the effects of site, practices, times and their interaction on soil nematode variables $(n=4)$

\begin{tabular}{|c|c|c|c|c|c|c|c|}
\hline $\begin{array}{l}\text { Nematode } \\
\text { Response Variable }\end{array}$ & $\begin{array}{l}\text { Site } \\
\text { (S) }\end{array}$ & $\begin{array}{l}\text { Practices } \\
\text { (P) }\end{array}$ & $\begin{array}{l}\text { Times } \\
(T)\end{array}$ & $S \times P$ & $\underset{T}{\text { Site } x}$ & $T \times P$ & $\begin{array}{l}S \times P \\
\times T\end{array}$ \\
\hline $\begin{array}{l}\text { Total nematode (ind } 100 \mathrm{~g}^{-1} \\
\text { dry soil) }\end{array}$ & 0.011 & 0.0905 & 0.083 & 0.803 & ¿. 001 & $\dot{0} 001$ & 0.165 \\
\hline Bacterivores (\%) & 0.062 & 0.564 & 0.131 & 0.018 & 0.356 & 0.264 & 0.002 \\
\hline Fungivores (\%) & 0.175 & 0.061 & 0.116 & 0.897 & 0.869 & 0.105 & 0.566 \\
\hline Omnivores(\%) & 0.157 & 0.382 & 0.756 & 0.299 & 0.092 & 0.483 & 0.472 \\
\hline Predators (\%) & 0.004 & 0.530 & 0.039 & 0.271 & $\hat{0}_{0.001}$ & 0.061 & 0.415 \\
\hline Herbivores (\%) & 0.462 & $<0.001$ & 0.053 & 0.193 & 0.002 & $\begin{array}{l}<.001 \\
0.00\end{array}$ & 0.423 \\
\hline Taxon richness & 0.143 & 0.155 & 0.141 & 0.143 & <. 001 & <. 001 & 0.012 \\
\hline Shannon diversity & 0.142 & 0.863 & 0.398 & 0.002 & 0.007 & 0.123 & $\begin{array}{l}<.001 \\
0.00\end{array}$ \\
\hline Evenness & 0.230 & 0.964 & 0.514 & 0.030 & 0.162 & 0.826 & 0.013 \\
\hline Enrichment index & 0.789 & 0.246 & 0.227 & 0.015 & 0.639 & $\dot{0} 001$ & 0.018 \\
\hline Structure index & 0.876 & 0.898 & 0.444 & 0.025 & 0.223 & 0.093 & 0.008 \\
\hline Maturity index & 0.769 & 0.995 & 0.701 & 0.033 & 0.008 & 0.858 & 0.072 \\
\hline Nematode Channel Ratio & $\hat{0}_{0.001}$ & 0.324 & 0.205 & 0.016 & 0.022 & 0.110 & 0.003 \\
\hline
\end{tabular}

Impact of practices on total nematode and trophic group abundances

A significant decrease in the total nematode abundance was observed six months after rubber tree cutting at both sites (Fig. 1). At the sandy site, no significant resilience was observed for any of the practices at any time. At the clay site, significant resilience of the total nematode abundance was observed from 12 to 24 months in practice with logging residue input (R1L1 and R2L1). However, in practice, without residues (ROL1), resilience only occurred at 24 months. 
Significant variations in the relative abundance of trophic groups across time were observed between the practices at both sites (Fig. 2). Bacterivores and herbivores were the dominant groups at both sites, regardless of practice and sampling date. At the sandy and clay sites, the proportion of herbivorous nematodes was negatively affected six months after rubber tree cutting. The sandy site was characterised by a higher proportion of bacterivorous nematodes across practices and sampling dates than clay sites (except at six months). At the clay site, an increase in the proportion of herbivores was observed in all plots after six months, except under practice ROLO. At the clay site, predatory nematodes appeared at 18 months in all plots in a low proportion. At both sites, the proportion of fungivorous nematodes was stable over time.

Impact of practices on nematodes structure

At both sites, a decrease in nematode descriptors was observed after six months, regardless of the trophic groups (Tables S2 and S3). At the sandy site, the free-living nematode abundance, bacterivores, omnivores, and Shannon diversity were more resilient between 12 and 18 months compared to 0 months in plot R2L1 only. However, we did not observe the resilience of nematode trophic groups (except for omnivores in the ROL1 practice) for the practices without logging residues (ROLO and ROL1). In R1L1 and R2L1, the fungivore nematode abundance drastically increased from 18 months compared to that at 0 months (Table S2). At the clay site, under R2L1 between 12 and 24 months, significant resilience of the abundances of almost all trophic groups was observed (Table S3). The species richness and converted Simpson and Shannon indices were integrated into the class of alpha diversity measures called Hill numbers. The alpha diversity of the nematode communities was negatively affected by rubber tree logging, depending on the site (Fig. 3). The diversity profiles showed higher taxonomic richness when $q=0$ under the practices with logging residue input over 12-24 months at both sites. At $q=1$, the highest diversity was observed under R1L1 from 12 to 18 months at both sites. However, at 24 months, the nematode community under R2L1 practice was most diverse at both sites. At the sandy site, when $\mathrm{q}=2$, R1L1 was most equitable at 12 and 18 months. At 24 months, the highest equitability was observed under R2L1. At the clay site, the equitability decreased over time with residues when $q=2$. We observed a significant difference among the different practices on each sampling date at both sites (Table S4).

Impact of practices on nematode ecological indices

No significant changes in the SI were observed under all practices across time after rubber tree cutting, except for practice R2L1 at the sandy site (Fig. 4A) and ROLO at the clay site (Fig. 4B). In the practices without logging residues, the El increased significantly after 12 months at the sandy site under ROL 1 , whereas at the clay site, the El decreased significantly from 6 to 24 months under ROLO and fluctuated at low levels over time under ROL1 (Fig. 4C and 4D).

Under the practices without logging residues (ROLO and ROL1), no significant variation in the MI was observed at either site, except under the ROLO practice at the clay site, where significant fluctuations in MI were observed every 6 months (Fig. 4E and 4F). However, in the practices with logging records (R1L1 and 
R2L1) at the sandy site, the MI was high up to 12 months, but drastically decreased at 18 and 24 months, with the exception of R2L1, under which it increased at 24 months.

At the sandy site, the nematode faunal profile before rubber tree cutting (TO) revealed that the food webs for old rubber were positioned within quadrats with limited and structured resources (quadrat C, Fig. S4). After 24 months, all practices were positioned in quadrat B, which is typical of an enrichment condition, except for practice ROLO. The same pattern was observed at the clay site, with the exception of practice ROLO, which was positioned in a depleted and degraded quadrat (quadrat D) at 24 months.

Impact of practices on the nematode beta diversity

We computed NMDS with Bray Curtis dissimilarity to represent nematode community composition under all practices at each site across time on a non-metric scale (Fig. 5). The NMDS showed that the patterns of the nematode community after rubber tree cutting were further away (resistance) from those of the old plantation. However, over time, the patterns observed under the practices with residues were closer to those before rubber tree cutting (resilience). A significant change related to the site (PERMANOVA, $F=10.844, R^{2}=0.032, P=0.001$, Table S5) was detected in the taxonomic composition of nematodes. At each site, these changes were influenced by both sampling date and practice (Tables S6 and S7).

Comparing the dissimilarity between practices and old rubber at each site, we observed a significant difference in the composition of the nematode community (Fig. 6). The Sorensen dissimilarity among all practices was relatively lower for practices with residue than for practices without. The species turnover (\% of new species compared to T0) in all practices at both sites varied significantly over time (Fig. 6). At 24 months after rubber tree cutting, the species turnover was important $(\sim 50 \%)$ under practices with only logging residues (R1L1 and R2L1) at the sandy site and under all practices with residues and legumes (ROL1, R1L1, and R2L1) at the clay site. Consequently, the level of taxon nestedness (species also present at T0) was rather low, below $30 \%$ under all practices at both sites, regardless of the sampling date.

Before rubber tree cutting, two taxa were highly dominant (abundance $\geq 200$ ind. $100 \mathrm{~g}^{-1}$ dry soil) in mature RP at the sandy site (Tylenchidae and Cephalobidae), one was moderately dominant (Rhabditidae), and one had low abundance (Leptonchidae). However, at 24 months, in addition to Tylenchidae, Cephalobidae, and Rhabditidae, five other dominant taxa appeared at the young RP (Table S8). At the clay site, only two taxa (Tylenchidae and Cephalobidae) were dominant in the field before the rubber tree cutting. At 24 months, 15 other dominant taxa were observed, in addition to Tylenchidae and Cephalobidae (Table S8).

\section{Discussion}

Importance of the physical soil conditions on nematodes

A main finding of our study is the pronounced "site" effect on all nematode parameters, such as diversity, abundance, distribution of trophic groups, and structure, and on their temporal changes following rubber 
tree cutting. The level of soil nematode community resilience following rubber tree cutting was highly dependent on the local site context. A strong difference between the two sites was the soil texture, that is, the soil texture was sandy-silty at the sandy site ( $10 \%$ clay) and silty-sandy at the clay site ( $23 \%$ clay). Soil texture is known to strongly affect soil nematode composition at both global (van den Hoogen et al. 2020) and local scales (Koenning et al. 1998; Olabiyi et al. 2009; Quist et al. 2019), with a stronger influence on nematodes than climate or land management (Renčo et al. 2020). We thus suppose that the between-site changes in soil texture could explain this significant site effect. However, little is known about the extent to which soil texture alters the temporal changes in soil nematodes following perturbation. In addition, we can exclude other soil properties involved in these nematode differences, such as total $\mathrm{P}$ content or $\mathrm{pH}$. Thus, more studies are needed.

Resistance of the soil nematodes communities to clear-cutting and land preparation

Most of the nematode parameters decreased significantly at both sites following rubber tree cutting and land preparation. This biological loss is thought to be related to plantation clearing, which involves soil compaction and habitat degradation by the heavy machinery used for mechanical cutting and logging residue extraction (Hartmann et al. 2012; Hartmann et al. 2014; Ranius et al. 2018). This hypothesis is supported by the well-known negative effects of soil compaction on nematode trophic groups (Bouwman and Arts 2000).

$\mathrm{Ml}$ is considered as a measure of environmental disturbance of nematode communities (Bongers, 1990); the higher the index, the higher the soil stability. In our study, the fluctuation in the MI under all practices over time could be explained by the sensitive nematode persisters (K-strategy species with high c-p value=3-5) disappearing and the number of colonisers ( $r$-strategy species with high $c-p$ value=1-2) increasing (Bongers, 1990; Porazinska et al. 1999). After rubber tree cutting, colonisers could occupy the niches of the disappeared persisters, which explains the increase in the maturity index at 12 months under all practices at both sites. Nematode persisters were the last group of nematodes to colonise a soil ecosystem after a disturbance due to their sensitivity (Villenave et al. 2018). These trends are similar to those reported by (Ewald et al. 2020), who found similar low MI values across all practices and depths, reflecting the soil disturbance in the arable soil of maize crops (Zea mays). The texture effect appeared to have a greater impact than compaction, because the nematode abundance decreased when the soil became less compact (Tables $\mathbf{S 9}$ and $\mathbf{S 1 0}$ ). The clay texture retained more moisture (Table S10) and allowed the nematodes to resist soil disturbance following clear-cutting.

Resilience of the soil nematodes communities to logging residues

We found that adding organic matter, such as legumes and logging residues, after clear-cutting and land preparation affected both the alpha and beta diversity of the soil nematode community. A strong negative effect on nematode abundance was observed under the practice without residues (ROLO) at the sandy site and for all sampling dates. Accordingly, the absence of cover crops is known to decrease the abundance of soil microbial populations (Leroy et al. 2009) and bacterivore and fungivore nematodes (Leslie et al. 2017; Kim et al. 2020). The absence of crops on these plots without residues could generate 
greater variability in soil temperature and moisture (Tables $\mathbf{S 9}$ and $\mathbf{S 1 0}$ ), which negatively affects nematode populations (Bakonyi et al. 2007). In contrast, the practices with logging residues (R1L1 and R2L1) had higher total nematode and trophic group abundances between 12 and 18 months. This positive contribution of organic matter application to the soil nematode abundance was previously reported along organic amendment gradients in annual crops (Pan et al. 2020) or following organic fertiliser application, but has never been reported in the context of tree plantations.

At sandy sites, the low resilience of the total nematode abundance observed under the practices without logging residues (ROLO and ROL1) was related to the low level of organic matter input (Liu et al. 2016). In contrast, for practices with logging residues, the low resilience values of nematodes could be attributed to the fast decomposition of logging residues under tropical conditions, because almost $80 \%$ of residues were decomposed after 24 months (data not shown), as previously reported in tropical rainforests (Krashevska et al. 2018). At the clay site, the low nematode abundance in plots without residues (ROL0 and ROL 1) could be related to both the low amount of residue input and carbon loss due to erosion, given the high slopes prevailing at this site (Guillaume et al. 2015).

Interestingly, organic management affected the total abundance more directly; for example, we found $\sim 100$ fold more bacterivore nematodes at 18 months in plots with logging residue than in plots with no residue at the sandy site. We observed a similar trend at the clay site, but at a lower level ( $21 \mathrm{fold}$ ). Several studies have reported a significant impact of field organic matter management practices on the nematode trophic composition (Freckman and Ettema 1993; Renčo et al. 2010). The high proportion of bacterivorous nematodes under practices with logging residues (R1L1 and R2L1) at the sandy site at 18 months underlines their active involvement in organic matter decomposition (Neher 2001). Furthermore, the high proportions of bacterivorous nematodes in all sites and on each sampling date suggested a significant bacterial-energy channel contribution to logging residue decomposition.

Generally, after anthropogenic disturbance of soil, the communities present, such as bacterivorous nematodes, are dominated by rapid growth (Ferris and Matute 2003). The low proportions of omnivores and predators under all practices at both sites are in accordance with the findings of (Wang and Hooks 2011), who reported that omnivorous and predatory nematodes were typically the last groups of nematodes to colonise a soil ecosystem after a disturbance due to their sensitivity (Villenave et al. 2018). The high SI values under most practices (>80) between 6 and 24 months suggest a more structured community than that on the previous dates (Ferris et al., 2001). The impact of logging residues on the SI value in tree plantations has never been addressed; however, in annual crops, such as sorghum plantations in Burkina Faso, Villenave et al. (2010) observed similar trends in SI (>75) in both unamended and amended plots.

In this study, at both sites, the nematode indices before rubber tree cutting (T0) indicated a structured food web with moderate soil enrichment, a high $\mathrm{C} / \mathrm{N}$ ratio, and fungal decomposition channels. At 24 months, the nematode profile under practices with residues R1L1 and R2L1 and with legumes only (ROL1) indicated a mature food web structure, high $\mathrm{N}$ concentration, low $\mathrm{C} / \mathrm{N}$ ratio, bacterial 
decomposition channels, and low to moderate levels of disturbance to the soil environment(Ferris 2010a; Ferris 2010b; Wang et al. 2019). These conditions are mainly due to the high quantities of carbon and organic $\mathrm{N}$ in the soil resulting from the decomposition of logging residues and legume litter. The effects of logging residue input on soil food webs have never been addressed in RP, but similar results have been reported in tea and walnut plantations (Li et al. 2014; Song et al. 2020). The restitution of harvest residues, such as organic matter, increases the resources available to the soil food web and supplies the soil ecosystem (Liu et al. 2019). Zhang et al. (2013) and Zhang et al. (2016) argued that soil food web resilience and ecosystem functions are affected by agricultural management practices.

The ratio (nestedness/Sorensen) of the nematode communities in each practice over time was low $(<0.5)$ in this study (data not shown), indicating that turnover was the major contributor to beta diversity. This indicates that, among the different practices, nematode composition was mostly due to species turnover, and less importantly due to differences in richness.

The changes in the dominant taxa at both sites between 0 and 24 months were likely associated with major changes in life strategies and trophic group composition. Indeed, the life-cycles of nematodes with short life-cycles may not be as visible, because they can produce several generations in one year, such as Tylenchidae, Aphelenchidae, and Rhabditidae (Verschoor et al. 2001). Generally, these observations indicate a continuous succession of nematode communities under different practices over time, probably due to changes in environmental conditions (Villenave et al. 2010). Under different practices, nematode communities tended to be in a dynamic equilibrium provided by the interchangeability of particular taxa under particular habitat conditions. However, the magnitude of the current assessment highlights the need for more intensive sampling and better understanding of the present taxa.

Implication for management: are logging residues a sustainable crop management in rubber plantations?

The negative impacts of rubber tree logging on soil health reflected by nematode communities should challenge farmers in their choice of machinery type and frequency of traffic, depending on the soil type, weather conditions, and acceptable degree of compaction. Logging residues and/or legume inputs could result in pest pressure that may increase over time at sites according to the practices employed. Meloidogyne, Pratylenchus, Dolichodorus, and Helicotylenchus are the main parasitic nematodes in RP. The high abundance of Meloidogyne found at the clay site indicates possible high pest pressure at this site. Monitoring the soil nematode composition is necessary for identifying pest risks due to the input of rubber residues and legumes. As rubber trees are usually cultivated in association with cover crops, the infectivity of nematodes in the roots of these plants should be examined by visual macroscopic inspection. Soil texture, which determines soil compaction and porosity (and, therefore, the availability of moisture and aeration for nematodes), is likely one of the most important soil characteristics related to free-living nematode abundance and plant-parasitic nematode infestations in crops (Moore and Lawrence 2013). Therefore, soil characteristics (such as bulk density) must be considered to maintain healthy soil for a sustainable cropping system. 


\section{Conclusions}

This study demonstrated that nematode communities in young RP were sensitive to clear-cutting and land preparation. The negative impact of rubber tree logging on the dynamics of nematode communities was revealed by the lower abundance, richness, beta diversity, and ecological indices. Our analysis suggested that the nematode community parameters were significantly more resilient in fields amended with logging residues. However, this resilience was more dependent on the local site conditions, such as soil texture, rather than the gradient of logging residue input. Monitoring soil nematode communities over 24 months after cutting was likely insufficient to ensure the full recovery of the initial nematode community structure. Further studies are required to assess the long-term impacts of organic matter input during the immature phase of RP.

\section{Abbreviations}

RP rubber plantation

C carbon

NCR nematode channel ratio

MI maturity index

El enrichment index

SI structure index

LMMs Linear mixed-effects models

ANOVA analysis of variance

NMDS non-metric multidimensional scaling

\section{Declarations}

Author contributions Kouakou Aymard : Conceptualization, Methodology, Data curation, Formal analysis, Investigation, Visualization, Writing original draft, Writing, review \& editing. Jean Trap : Visualization, Writing, review \& editing. Sidy Diakhaté : Formal analysis, Writing, review \& editing. Thibaut Perron : Data curation, Investigation, Writing - review \& editing. Kolo Yéo : Validation, Writing, review \& editing, Supervision. Frédéric Gay : Methodology, Conceptualization, Project administration, Funding acquisition. Alain Brauman : Conceptualization, Methodology, Validation, Writing, review \& editing, Supervision, Project administration.

Conflicts of interest All authors have no conflicts of interest. 


\section{Acknowledgments}

We thank the financial companies SIPH, SOCFIN, and MICHELIN for supporting this project through the "FERTIM" program. We thank SAPH and SOGB, who provided logistical and technical support, in addition to funding. This study was also supported by the "Institut Français du Caoutchouc" (IFC). Additional funding was provided by the IRD PhD Grant Program (ARTS, 2019).

\section{References}

1. Alam MdK, Bell RW, Haque ME, Kader MA (2018) Minimal soil disturbance and increased residue retention increase soil carbon in rice-based cropping systems on the Eastern Gangetic Plain. Soil Tillage Res 183:28-41. https://doi.org/10.1016/j.still.2018.05.009

2. APROMAC (2021) Association des Professionnels du Caoutchouc Naturel de Côte d'Ivoire. In: Bienvenue Sur Site Off. L039APROMAC. https://apromac.ci/apromac-en-action-le-succes-de-la-filierehevea-en-chiffre/. Accessed 21 Jun 2021

3. Arcand MM, Knight JD, Farrell RE (2014) Differentiating between the supply of $\mathrm{N}$ to wheat from above and belowground residues of preceding crops of pea and canola. Biol Fertil Soils 50:563-570. https://doi.org/10.1007/s00374-013-0877-4

4. Baijing Z, Jingrong X, Rong $X$ et al (2019) Effect of soil nematode functional guilds on plant growth and aboveground herbivores. Biodivers Sci 27:409-418. https://doi.org/10.17520/biods.2019006

5. Bakonyi G, Nagy P, Kovács-Láng E et al (2007) Soil nematode community structure as affected by temperature and moisture in a temperate semiarid shrubland. Appl Soil Ecol 37:31-40. https://doi.org/10.1016/j.apsoil.2007.03.008

6. Baselga A (2010) Partitioning the turnover and nestedness components of beta diversity: Partitioning beta diversity. Glob Ecol Biogeogr 19:134-143. https://doi.org/10.1111/j.1466-8238.2009.00490.x

7. Baselga A, Orme CDL, Villeger S et al (2021)Partitioning Beta Diversity into Turnover and Nestedness Components

8. Bongers T (1990) The maturity index: an ecological measure of environmental disturbance based on nematode species composition. Oecologia 83:14-19. https://doi.org/10.1007/BF00324627

9. Bouwman LA, Arts WBM (2000) Effects of soil compaction on the relationships between nematodes, grass production and soil physical properties. Appl Soil Ecol 14:213-222. https://doi.org/10.1016/S0929-1393(00)00055-X

10. Broughton WJ (1976) Effect of various covers on soil fertility under Hevea brasiliensis muell. arg. and on growth of the tree. Agro-Ecosyst 3:147-170. https://doi.org/10.1016/0304-3746(76)90113-X

11. Carron MP, Pierrat M, Snoeck D et al (2015) Temporal variability in soil quality after organic residue application in mature oil palm plantations. Soil Res 53:205. https://doi.org/10.1071/SR14249

12. Chambon B, Dao XL, Tongkaemkaew U, Gay F, WHAT DETERMINE SMALLHOLDERS' FERTILIZATION PRACTICES DURING THE MATURE PERIOD OF RUBBER PLANTATIONS IN (2018) THAILAND? Exp Agric 54:824-841. https://doi.org/10.1017/S0014479717000400 
13. Chao A, Chiu C-H, Jost L (2014) Unifying Species Diversity, Phylogenetic Diversity, Functional Diversity, and Related Similarity and Differentiation Measures Through Hill Numbers. Annu Rev Ecol Evol Syst 45:297-324. https://doi.org/10.1146/annurev-ecolsys-120213-091540

14. Cortois R, Veen GFC, Duyts $\mathrm{H}$ et al (2017) Possible mechanisms underlying abundance and diversity responses of nematode communities to plant diversity. Ecosphere 8:e01719. https://doi.org/10.1002/ecs2.1719

15. de Mendiburu $P$ (2020) Package "agricolae\&\#8221

16. Delgado-Baquerizo M, Reich PB, Trivedi $C$ et al (2020) Multiple elements of soil biodiversity drive ecosystem functions across biomes. Nat Ecol Evol 4:210-220. https://doi.org/10.1038/s41559-0191084-y

17. Dobrovolski R, Melo AS, Cassemiro FAS, Diniz-Filho JAF (2012) Climatic history and dispersal ability explain the relative importance of turnover and nestedness components of beta diversity: Climatic history and beta diversity. Glob Ecol Biogeogr 21:191-197. https://doi.org/10.1111/j.14668238.2011.00671.x

18. Ewald M, Glavatska O, Ruess L (2020) Effects of resource manipulation on nematode community structure and metabolic footprints in an arable soil across time and depth. Nematology 22:10251043. https://doi.org/10.1163/15685411-bja10009

19. Fageria NK, Baligar VC, Bailey BA (2005) Role of Cover Crops in Improving Soil and Row Crop Productivity. Commun Soil Sci Plant Anal 36:2733-2757.

https://doi.org/10.1080/00103620500303939

20. FAO (2021) FAOSTAT Online Statistical Service. http://www.fao.org/faostat/fr/\#home. Accessed 21 Jun 2021

21. Ferris H (2010a) Contribution of Nematodes to the Structure and Function of the Soil Food Web. J Nematol 42:63-67

22. Ferris $\mathrm{H}$ (2010b) Form and function: Metabolic footprints of nematodes in the soil food web. Eur $\mathrm{J}$ Soil Biol 46:97-104. https://doi.org/10.1016/j.ejsobi.2010.01.003

23. Ferris $H$, Bongers $T$ (2009) Indices developed specifically for analysis of nematode assemblages. In: Wilson MJ, Kakouli-Duarte T (eds) Nematodes as environmental indicators. CABI, Wallingford, pp 124-145

24. Ferris $\mathrm{H}$, Matute MM (2003) Structural and functional succession in the nematode fauna of a soil food web. Appl Soil Ecol 23:93-110. https://doi.org/10.1016/S0929-1393(03)00044-1

25. Fiscusi DA, Neher DA (2022) Distinguishing Sensitivity of Free-Living Soil Nematode Genera to Physical and Chemical Disturbances. Ecol Appl 12:12

26. Franco ALC, Sobral BW, Silva ALC, Wall DH (2019) Amazonian deforestation and soil biodiversity. Conserv Biol 33:590-600. https://doi.org/10.1111/cobi.13234

27. Freckman DW, Ettema CH (1993) Assessing nematode communities in agroecosystems of varying human intervention. Agric Ecosyst Environ 45:239-261. https://doi.org/10.1016/01678809(93)90074-Y 
28. Gale WJ, Cambardella CA (2002) Carbon Dynamics of Surface Residue- and Root-Derived Organic Matter Under Simulated No-Till. Soil Sci Soc Am J 66:2040-2040.

https://doi.org/10.2136/sssaj2002.2040

29. Gao D, Wang X, Fu S, Zhao J (2017) Legume Plants Enhance the Resistance of Soil to Ecosystem Disturbance. Front Plant Sci 8:1295. https://doi.org/10.3389/fpls.2017.01295

30. Gotelli NJ, Chao A (2013) Measuring and Estimating Species Richness, Species Diversity, and Biotic Similarity from Sampling Data. Encyclopedia of Biodiversity. Elsevier, pp 195-211

31. Guillaume T, Damris M, Kuzyakov Y (2015) Losses of soil carbon by converting tropical forest to plantations: erosion and decomposition estimated by $\delta^{13} \mathrm{C}$. Glob Change Biol 21:3548-3560. https://doi.org/10.1111/gcb.12907

32. Hartmann M, Howes CG, VanInsberghe D et al (2012) Significant and persistent impact of timber harvesting on soil microbial communities in Northern coniferous forests. ISME J 6:2199-2218. https://doi.org/10.1038/ismej.2012.84

33. Hartmann M, Niklaus PA, Zimmermann S et al (2014) Resistance and resilience of the forest soil microbiome to logging-associated compaction. ISME J 8:226-244. https://doi.org/10.1038/ismej.2013.141

34. Hothorn T, Bretz F, Westfall P (2008) Simultaneous Inference in General Parametric Models. Biom J 50:346-363. https://doi.org/10.1002/bimj.200810425

35. Huang Z, He Z, Wan X et al (2013) Harvest residue management effects on tree growth and ecosystem carbon in a Chinese fir plantation in subtropical China. Plant Soil 364:303-314. https://doi.org/10.1007/s11104-012-1341-1

36. Ibrahim M, Cao C-G, Zhan M et al (2015) Changes of CO2 emission and labile organic carbon as influenced by rice straw and different water regimes. Int J Environ Sci Technol 12:263-274. https://doi.org/10.1007/s13762-013-0429-3

37. Irshad U, Villenave C, Brauman A, Plassard C (2011) Grazing by nematodes on rhizosphere bacteria enhances nitrate and phosphorus availability to Pinus pinaster seedlings. Soil Biol Biochem 43:2121-2126. https://doi.org/10.1016/j.soilbio.2011.06.015

38. Kim N, Zabaloy MC, Guan K, Villamil MB (2020) Do cover crops benefit soil microbiome? A metaanalysis of current research. Soil Biol Biochem 142:107701. https://doi.org/10.1016/j.soilbio.2019.107701

39. Koenning SR, Anand SC, Wrather JA (1998) Effect-of Within-field Variation in Soil Texture on Heterodera glycines and Soybean Yield. J Nematol 20:373-380

40. Krashevska V, Kudrin AA, Widyastuti R, Scheu S (2019) Changes in Nematode Communities and Functional Diversity With the Conversion of Rainforest Into Rubber and Oil Palm Plantations. Front Ecol Evol 7:487. https://doi.org/10.3389/fevo.2019.00487

41. Krashevska V, Malysheva E, Klarner B et al (2018) Micro-decomposer communities and decomposition processes in tropical lowlands as affected by land use and litter type. Oecologia 187:255-266. https://doi.org/10.1007/s00442-018-4103-9 
42. Kuznetsova A, Brockhoff PB, Christensen RHB (2017) Package: Tests in Linear Mixed Effects Models. J Stat Softw 82. https://doi.org/10.18637/jss.v082.i13

43. Lan G, Li Y, Jatoi MT et al (2017) Change in Soil Microbial Community Compositions and Diversity Following the Conversion of Tropical Forest to Rubber Plantations in Xishuangbanan, Southwest China. Trop Conserv Sci 10:194008291773323. https://doi.org/10.1177/1940082917733230

44. Lassauce A, Lieutier F, Bouget C (2012) Woodfuel harvesting and biodiversity conservation in temperate forests: Effects of logging residue characteristics on saproxylic beetle assemblages. Biol Conserv 147:204-212. https://doi.org/10.1016/j.biocon.2012.01.001

45. Leroy B, Reheul D, Moens M et al (2009) Short-term nematode population dynamics as influenced by the quality of exogenous organic matter. Nematology 11:23-38.

https://doi.org/10.1163/156854108X398381

46. Leslie AW, Wang K-H, Meyer SLF et al (2017) Influence of cover crops on arthropods, free-living nematodes, and yield in a succeeding no-till soybean crop. Appl Soil Ecol 117-118:21-31. https://doi.org/10.1016/j.apsoil.2017.04.003

47. Li J, Peng P, Zhao J (2020) Assessment of soil nematode diversity based on different taxonomic levels and functional groups. Soil Ecol Lett 2:33-39. https://doi.org/10.1007/s42832-019-0019-5

48. Li X, Liu Q, Liu Z et al (2014) Effects of organic and other management practices on soil nematode communities in tea plantation: a case study in southern China. J Plant Nutr Soil Sci 177:604-612. https://doi.org/10.1002/jpln.201300610

49. Liu C-A, Liang M-Y, Nie Y et al (2019) The conversion of tropical forests to rubber plantations accelerates soil acidification and changes the distribution of soil metal ions in topsoil layers. Sci Total Environ 696:134082. https://doi.org/10.1016/j.scitotenv.2019.134082

50. Liu C-A, Nie Y, Zhang Y-M et al (2018) Introduction of a leguminous shrub to a rubber plantation changed the soil carbon and nitrogen fractions and ameliorated soil environments. Sci Rep 8:17324. https://doi.org/10.1038/s41598-018-35762-0

51. Liu T, Chen X, Hu F et al (2016) Carbon-rich organic fertilizers to increase soil biodiversity: Evidence from a meta-analysis of nematode communities. Agric Ecosyst Environ 232:199-207. https://doi.org/10.1016/j.agee.2016.07.015

52. Liu W, Luo Q, Li J et al (2015) The effects of conversion of tropical rainforest to rubber plantation on splash erosion in Xishuangbanna, SW China. Hydrol Res 46:168-174.

https://doi.org/10.2166/nh.2013.109

53. Marcon E, Hérault B (2015) : An R Package to Measure and Partition Diversity. J Stat Softw 67. https://doi.org/10.18637/jss.v067.i08. entropart

54. Meng L-Z, Martin K, Weigel A, Liu J-X (2012) Impact of rubber plantation on carabid beetle communities and species distribution in a changing tropical landscape (southern Yunnan, China). J Insect Conserv 16:423-432. https://doi.org/10.1007/s10841-011-9428-1

55. Missanjo E, Kamanga-Thole G (2014) Impact of Site Disturbances from Harvesting and Logging on Soil Physical Properties and Pinus kesiya Tree Growth. Int Sch Res Not 2014:1-7. 
https://doi.org/10.1155/2014/323626

56. Moore SR, Lawrence KS (2013) The Effect of Soil Texture and Irrigation on Rotylenchulus reniformis and Cotton. J Nematol 45:99-105

57. Neher DA (2001) Role of Nematodes in Soil Health and Their Use as Indicators. J Nematol 33:161168

58. Oksanen J, Blanchet FG, Kindt R et al (2019) Vegan: community ecology package. R package version 2.5-4

59. Oku E, Iwara A, Ekukinam E (2012) Effects of Age of Rubber (Hevea brasiliensis Muell Arg.) plantations on $\mathrm{pH}$, organic carbon, organic matter, nitrogen and micronutrient status of ultisols in the humid forest zone of nigeria. Kasetsart J 46:684-693

60. Olabiyi TI, Olayiwola AO, Oyediran GO (2009) Influence of Soil Textures on Distribution of Phytonematodes in the South Western Nigeria. World J Agric Sci 5:557-560, 2009

61. Pan F, Han X, Li N et al (2020) Effect of organic amendment amount on soil nematode community structure and metabolic footprints in soybean phase of a soybean-maize rotation on Mollisols. Pedosphere 30:544-554. https://doi.org/10.1016/S1002-0160(17)60432-6

62. Perron T, Kouakou A, Simon $\mathrm{C}$ et al (2021a) Logging residues promote rapid restoration of soil health after clear-cutting of rubber plantations at two sites with contrasting soils in Africa. Sci Total Environ 151526. https://doi.org/10.1016/j.scitotenv.2021.151526

63. Perron T, Mareschal L, Laclau J-P et al (2021b) Dynamics of biomass and nutrient accumulation in rubber (Hevea brasiliensis) plantations established on two soil types: Implications for nutrient management over the immature phase. Ind Crops Prod 159:113084.

https://doi.org/10.1016/j.indcrop.2020.113084

64. Pielou EC (1975) Ecological diversity. Limnol Oceanogr 22:174-174. https://doi.org/10.4319/lo.1977.22.1.0174b

65. Porazinska DL, Duncan LW, McSorley R, Graham JH (1999) Nematode communities as indicators of status and processes of a soil ecosystem in ${ }^{-}$uenced by agricultural management practices. Appl Soil Ecol 13:69-86

66. Pothula SK, Grewal PS, Auge RM et al (2019) Agricultural intensification and urbanization negatively impact soil nematode richness and abundance: a meta-analysis. J Nematol 51:1-17. https://doi.org/10.21307/jofnem-2019-011

67. Puissant J, Villenave C, Chauvin C et al (2021) Quantification of the global impact of agricultural practices on soil nematodes: A meta-analysis. Soil Biol Biochem 161:108383. https://doi.org/10.1016/j.soilbio.2021.108383

68. Quénéhervé P (1998) Population of nematodes in soils under banana cv. Poyo in the Ivory Coast: 2 . Influence of soil texture, $\mathrm{pH}$ and organic matter on nematode populations. Rev Nématologie 11:245251

69. Quist CW, Gort G, Mooijman P et al (2019) Spatial distribution of soil nematodes relates to soil organic matter and life strategy. Soil Biol Biochem 136:107542. 
https://doi.org/10.1016/j.soilbio.2019.107542

70. Ranius T, Hämäläinen A, Egnell G et al (2018) The effects of logging residue extraction for energy on ecosystem services and biodiversity: A synthesis. J Environ Manage 209:409-425. https://doi.org/10.1016/j.jenvman.2017.12.048

71. Renčo M, Gömöryová E, Čerevková A (2020) The effect of soil type and ecosystems on the soil nematode and microbial communities. Helminthologia 57:129-144. https://doi.org/10.2478/helm2020-0014

72. Renčo M, Sasanelli N, D’Addabbo T, Papajová I (2010) Soil nematode community changes associated with compost amendments. Nematology 12:681-692. https://doi.org/10.1163/138855409X12584413195491

73. RStudio T, RStudio (2020)PBC, Boston, MA

74. Seinhorst JW (1962) Extraction Methods for Nematodes Inhabiting Soil. Progress in Soil Zoology. Butterworths, London, pp 243-256

75. Shannon CE (1948) A Mathematical Theory of Communication. Bell Syst Tech J 27:379-423

76. Si X, Baselga A, Ding P (2015) Revealing Beta-Diversity Patterns of Breeding Bird and Lizard Communities on Inundated Land-Bridge Islands by Separating the Turnover and Nestedness Components. PLoS ONE 10:e0127692. https://doi.org/10.1371/journal.pone.0127692

77. Singh D, Slik JWF, Jeon Y-S et al (2019) Tropical forest conversion to rubber plantation affects soil micro- \& mesofaunal community \& diversity. Sci Rep 9:5893. https://doi.org/10.1038/s41598-01942333-4

78. Snapp SS, Swinton SM, Labarta R et al (2005) Evaluating Cover Crops for Benefits, Costs and Performance within Cropping System Niches. Agron J 97:322-332. https://doi.org/10.2134/agronj2005.0322a

79. Song D, Tariq A, Pan K et al (2020) Effects of straw mulching practices on soil nematode communities under walnut plantation. Sci Rep 10:15351. https://doi.org/10.1038/s41598-020$72530-5$

80. Tondoh JE, Dimobe K, Guéi AM et al (2019) Soil Health Changes Over a 25-Year Chronosequence From Forest to Plantations in Rubber Tree (Hevea brasiliensis) Landscapes in Southern Côte d'Ivoire: Do Earthworms Play a Role? Front Environ Sci 7:73. https://doi.org/10.3389/fenvs.2019.00073

81. Trap J, Bonkowski M, Plassard C et al (2016) Ecological importance of soil bacterivores for ecosystem functions. Plant Soil 398:1-24. https://doi.org/10.1007/s11104-015-2671-6

82. Trap J, Ranoarisoa MP, Raharijaona S et al (2021) Agricultural Practices Modulate the Beneficial Activity of Bacterial-Feeding Nematodes for Plant Growth and Nutrition: Evidence from an Original Intact Soil Core Technique. Sustainability 13:7181. https://doi.org/10.3390/su13137181

83. van den Hoogen J, Geisen S, Wall DH et al (2020) A global database of soil nematode abundance and functional group composition. Sci Data 7:103. https://doi.org/10.1038/s41597-020-0437-3 
84. Verschoor BC, de Goede RGM, de Hoop J-W, de Vries FW (2001) Seasonal dynamics and vertical distribution of plant-feeding nematode communities in grasslands. Pedobiologia 45:213-233. https://doi.org/10.1078/0031-4056-00081

85. Villenave C, Saj S, Pablo A-L et al (2010) Influence of long-term organic and mineral fertilization on soil nematofauna when growing Sorghum bicolor in Burkina Faso. Biol Fertil Soils 46:659-670. https://doi.org/10.1007/s00374-010-0471-y

86. Villenave C, Séré G, Schwartz C et al (2018) Rapid Changes in Soil Nematodes in the First Years after Technosol Construction for the Remediation of an Industrial Wasteland. Eurasian Soil Sci 51:12661273. https://doi.org/10.1134/S1064229318100149

87. Wang K-H, Hooks CRR (2011) Managing Soil Health and Soil Health Bioindicators through the Use of Cover Crops and other Sustainable Practices. 18

88. Wang Z, Zhang Q, Staley C et al (2019) Impact of long-term grazing exclusion on soil microbial community composition and nutrient availability. Biol Fertil Soils 55:121-134. https://doi.org/10.1007/s00374-018-01336-5

89. Xiao HF, Tian YH, Zhou HP et al (2014) Intensive rubber cultivation degrades soil nematode communities in Xishuangbanna, southwest China. Soil Biol Biochem 76:161-169. https://doi.org/10.1016/j.soilbio.2014.05.012

90. Yeates GW (2003) Nematodes as soil indicators: functional and biodiversity aspects. Biol Fertil Soils 37:199-210. https://doi.org/10.1007/s00374-003-0586-5

91. Yeates GW, Bongers T Feeding Habits in Soil Nematode Families and Genera--An Outline for Soil Ecologists. 17

92. Yeates GW, Bongers T, De Goede RGM et al (1993) Feeding Habits in Soil Nematode Families and Genera-An Outline for Soil Ecologists. J Nematol 25:315-331

93. Zhang S, Li Q, Lü Y et al (2013) Contributions of soil biota to $C$ sequestration varied with aggregate fractions under different tillage systems. Soil Biol Biochem 62:147-156. https://doi.org/10.1016/j.soilbio.2013.03.023

94. Zhang Z, Zhang X, Xu M et al (2016) Responses of soil micro-food web to long-term fertilization in a wheat-maize rotation system. Appl Soil Ecol 98:56-64. https://doi.org/10.1016/j.apsoil.2015.09.008

\section{Figures}


SAPH

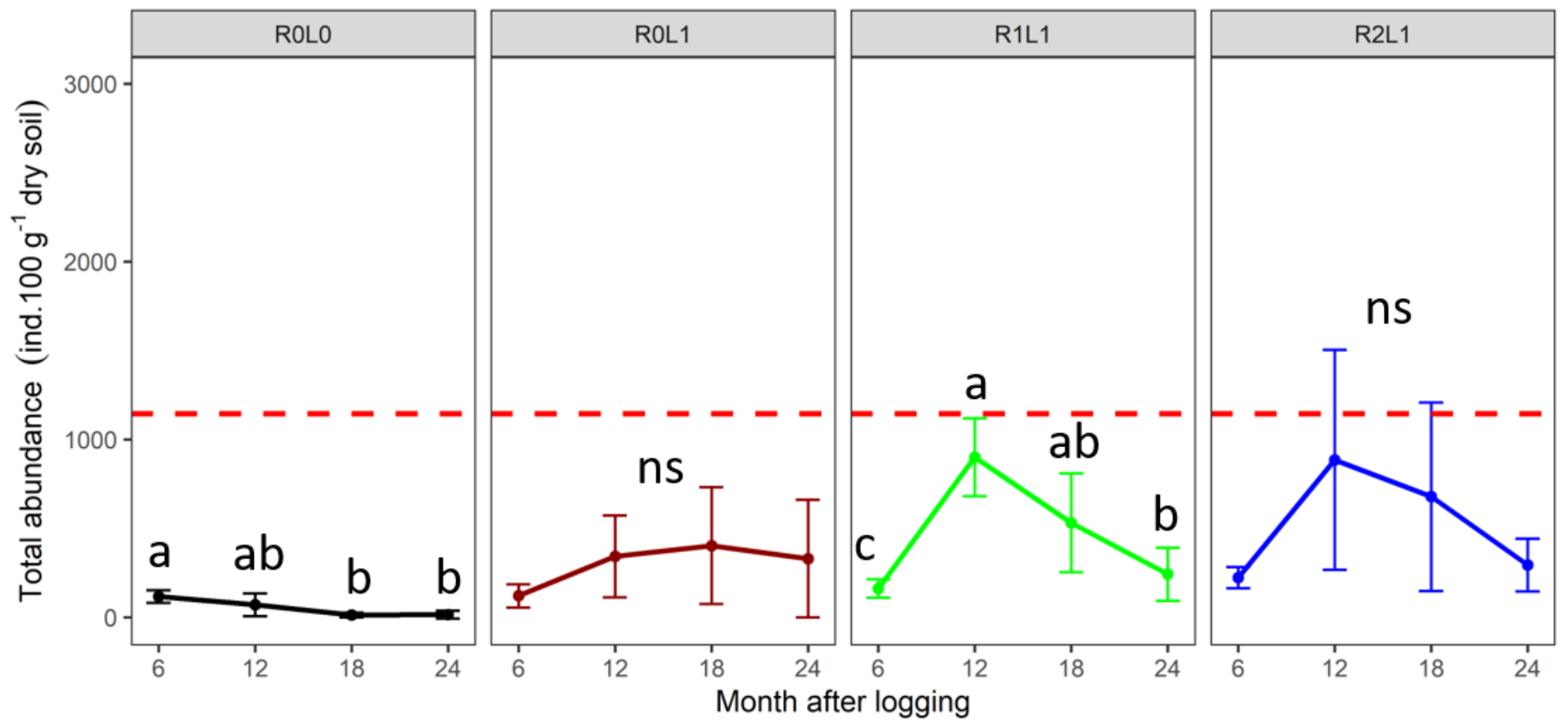

SOGB
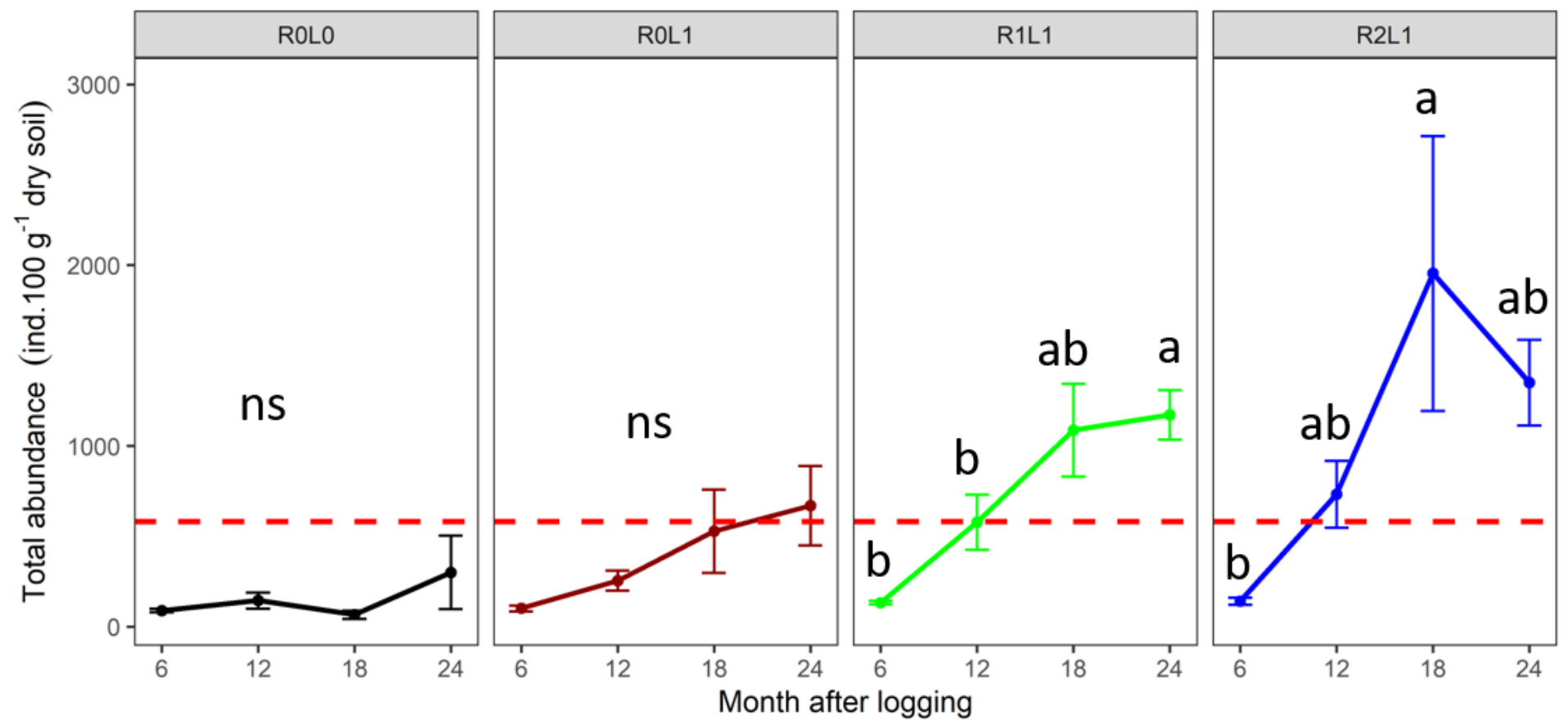

Figure 1

Temporal changes in total nematode abundance after logging according to practices and sites. The different letters indicate the significant differences between practices at each sampling date according to Tukey's post hoc test. ns: no significant difference $(P>0.05)$. SAPH, sandy site; SOGB, clay site; ROL0, no legumes or residues; ROL1, legume (Pueraria phaseoloides); R1L1, stump + leaf + fine branches; R2L1, $\mathrm{R} 1 \mathrm{~L} 1+$ trunk. The standard errors of mean are represented by the error bars $(n=4)$. The red dashed line corresponds to the average of the total abundance measured for T0 (before logging). 
SAPH
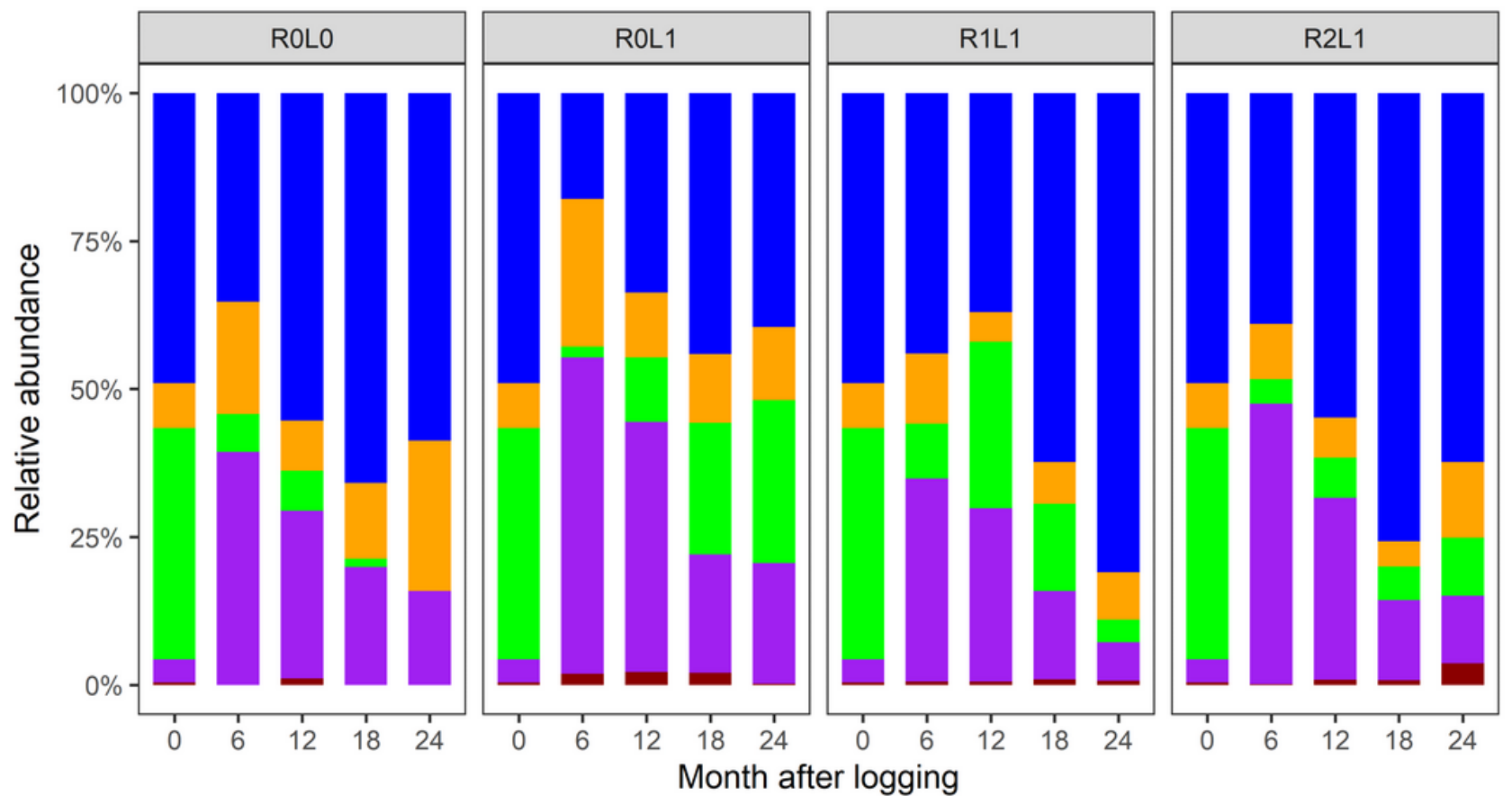

Trophic groups

Month after logging

SOGB
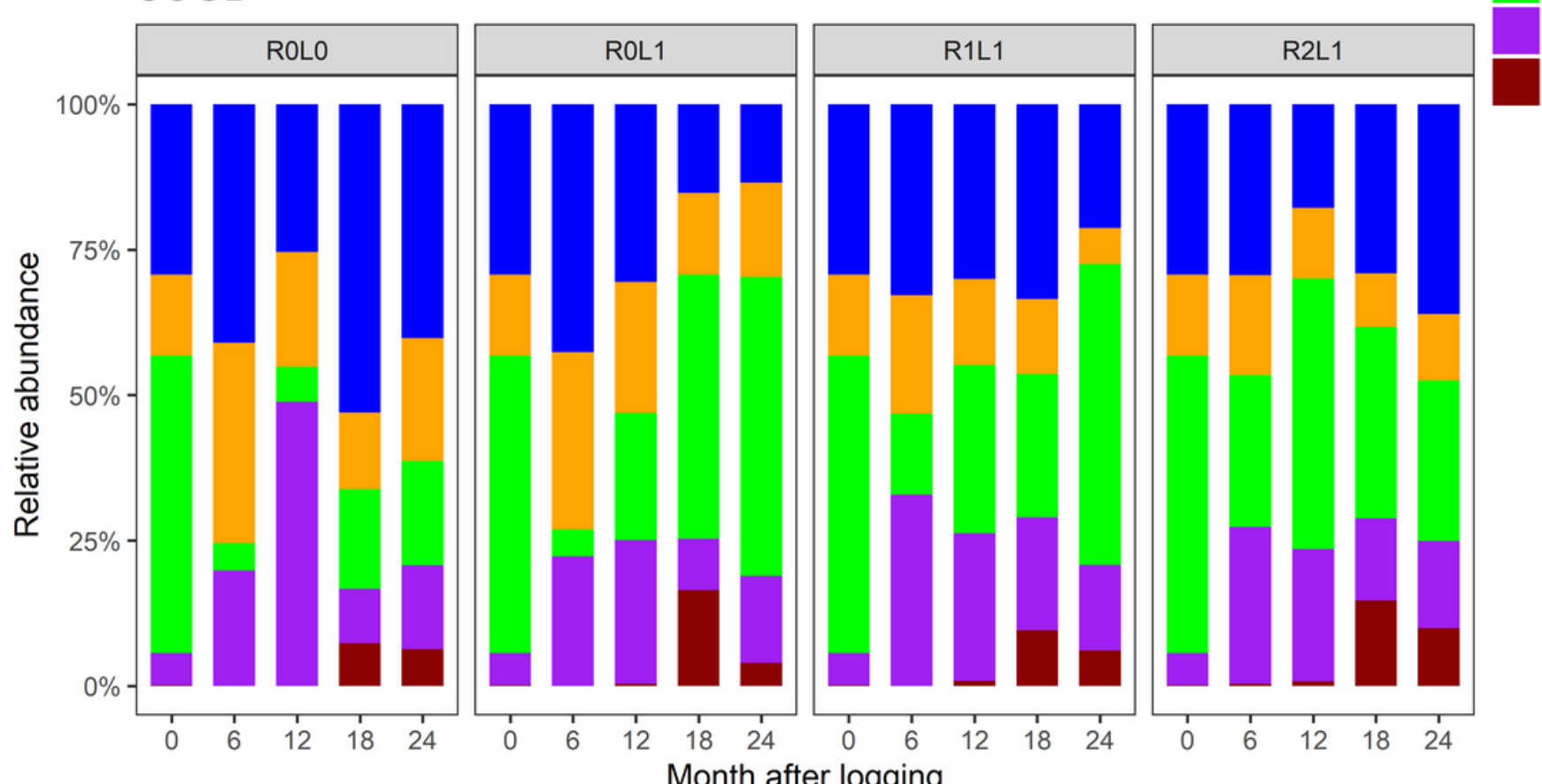

Fungivores

Herbivores

Omnivores

Predators

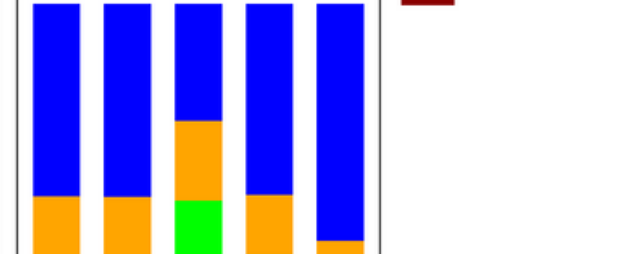

\section{Figure 2}

Changes in relative abundance of nematodes in practices at both sites. SAPH, sandy site; SOGB, clay site; R0L0, no legumes or residues; ROL1, legume (Pueraria phaseoloides); R1L1, stump + leaf + fine branches; R2L1, R1L1+ trunk. 

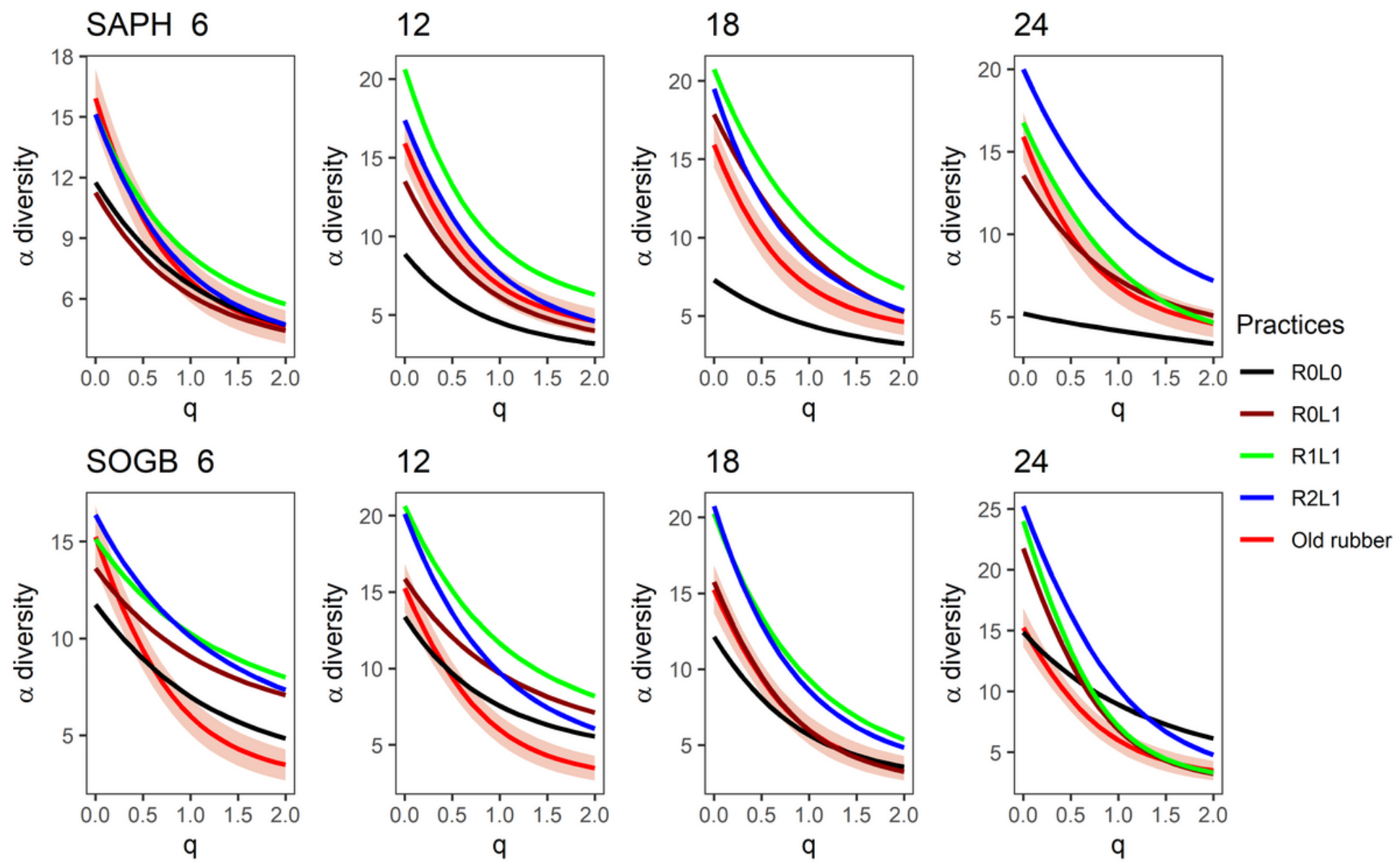

Figure 3

The Hill number-based diversity profiles of soil nematode at both sites for increasing order q values ( 0 to 2). $95 \%$ confidence interval have been added for Old rubber curve. SAPH, sandy site; SOGB, clay site; R0L0, no legumes or residues; ROL1, legume (Pueraria phaseoloides); R1L1, stump + leaf + fine branches; R2L1, R1L1+ trunk. 
A SAPH

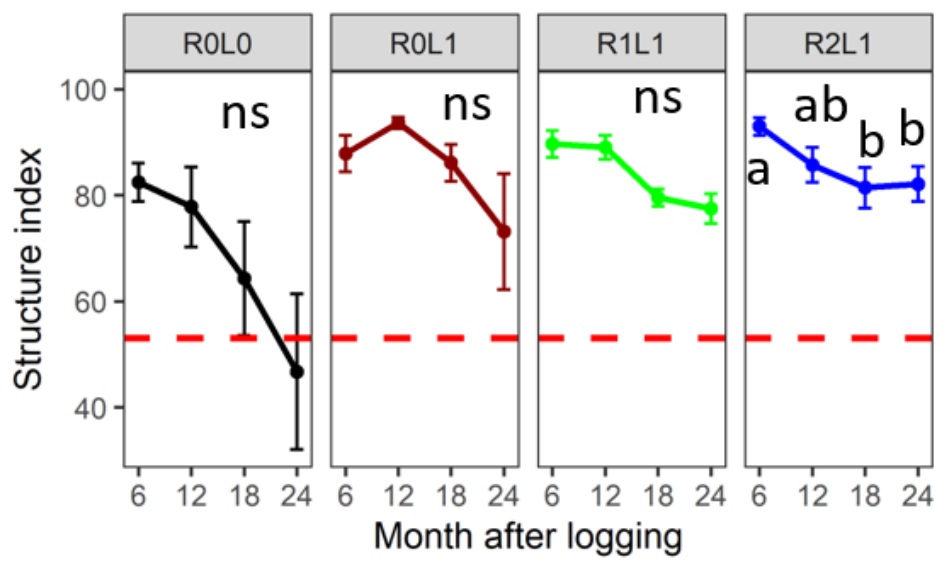

C SAPH

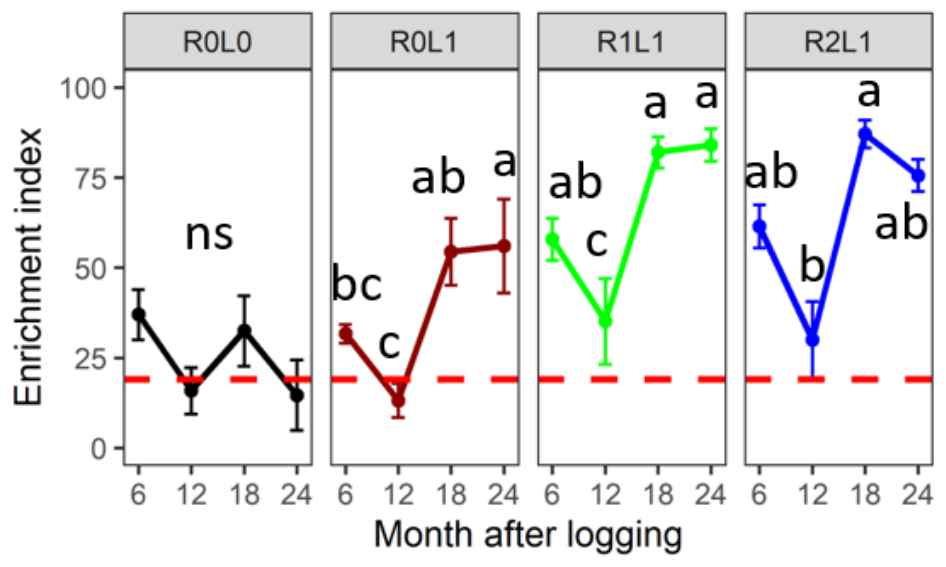

E SAPH

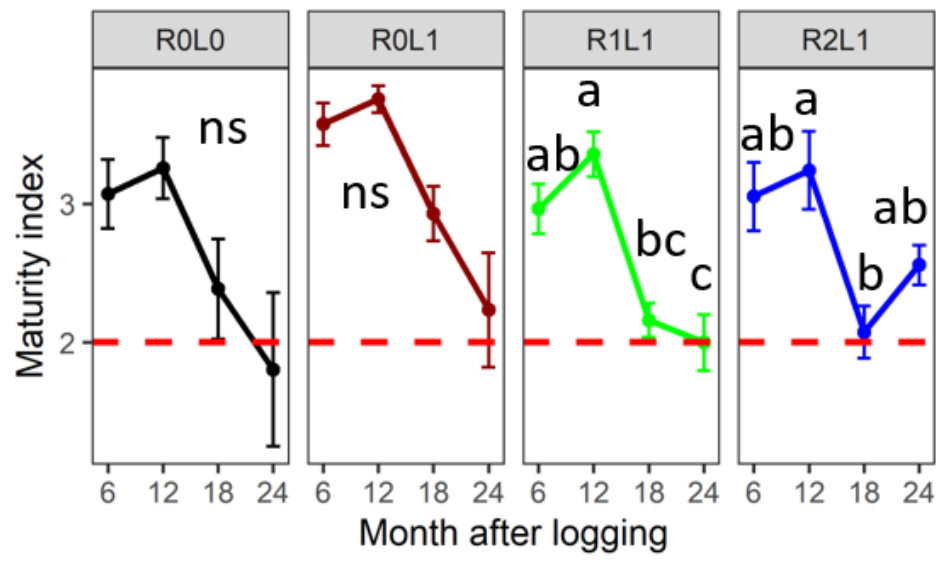

B SOGB

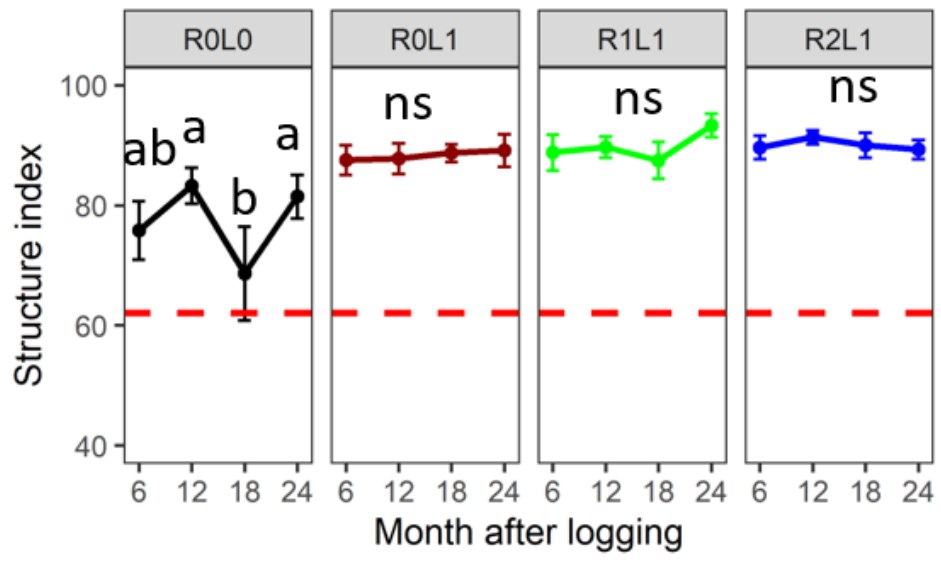

D SOGB

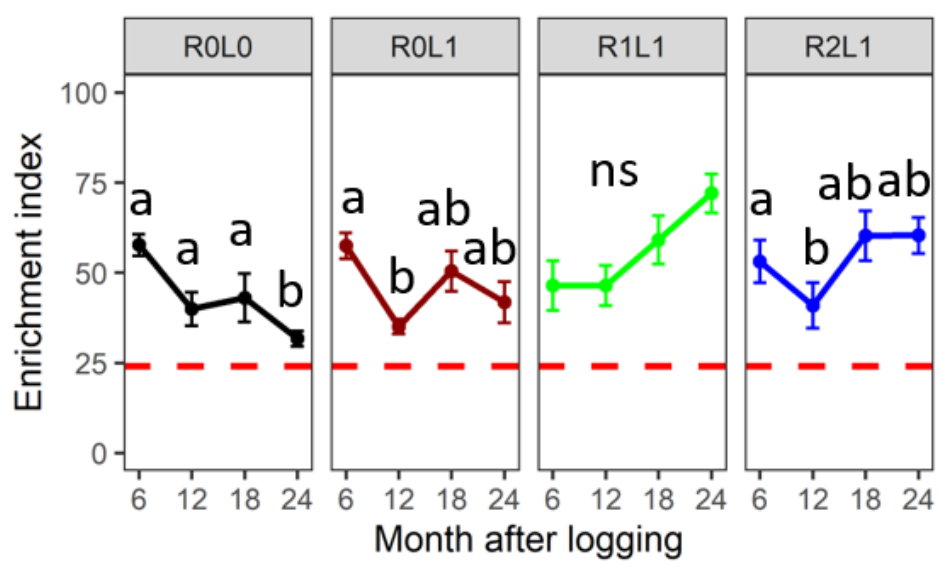

F SOGB

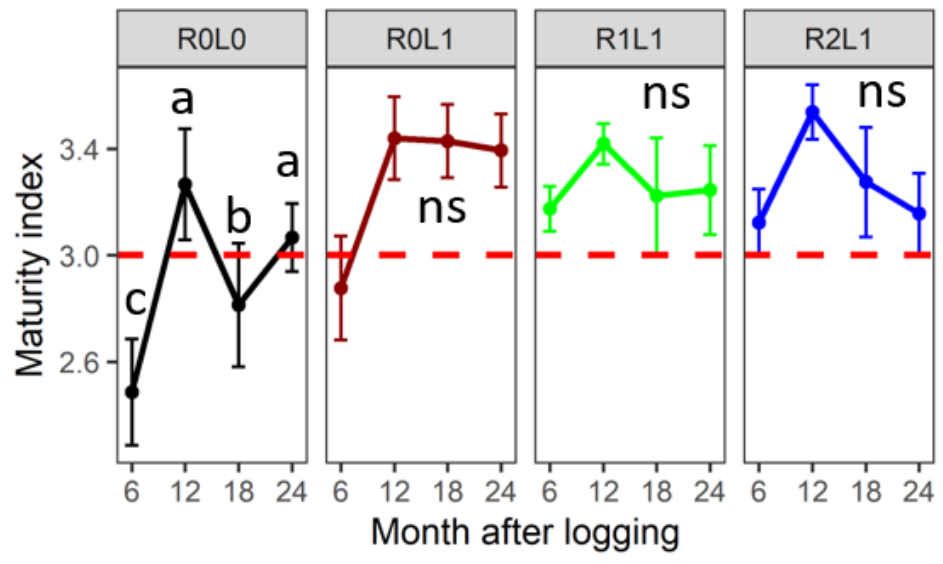

Figure 4

Temporal changes of nematode ecological index after logging according to practices and sites. The different letters indicate the signicant differences between practices at each sampling date according to Tukey's post hoc analysis. ns: no significant difference ( $P>0.05)$. SAPH, sandy site; SOGB, clay site; ROL0, no legumes or residues; R0L1, legume (Pueraria phaseoloides); R1L1, stump + leaf + fine branches; R2L1, $\mathrm{R} 1 \mathrm{~L} 1+$ trunk. The standard errors of mean are represented by the error bars $(\mathrm{n}=4)$. The red dashed line corresponds to the average of the index measured for T0 (before logging). 

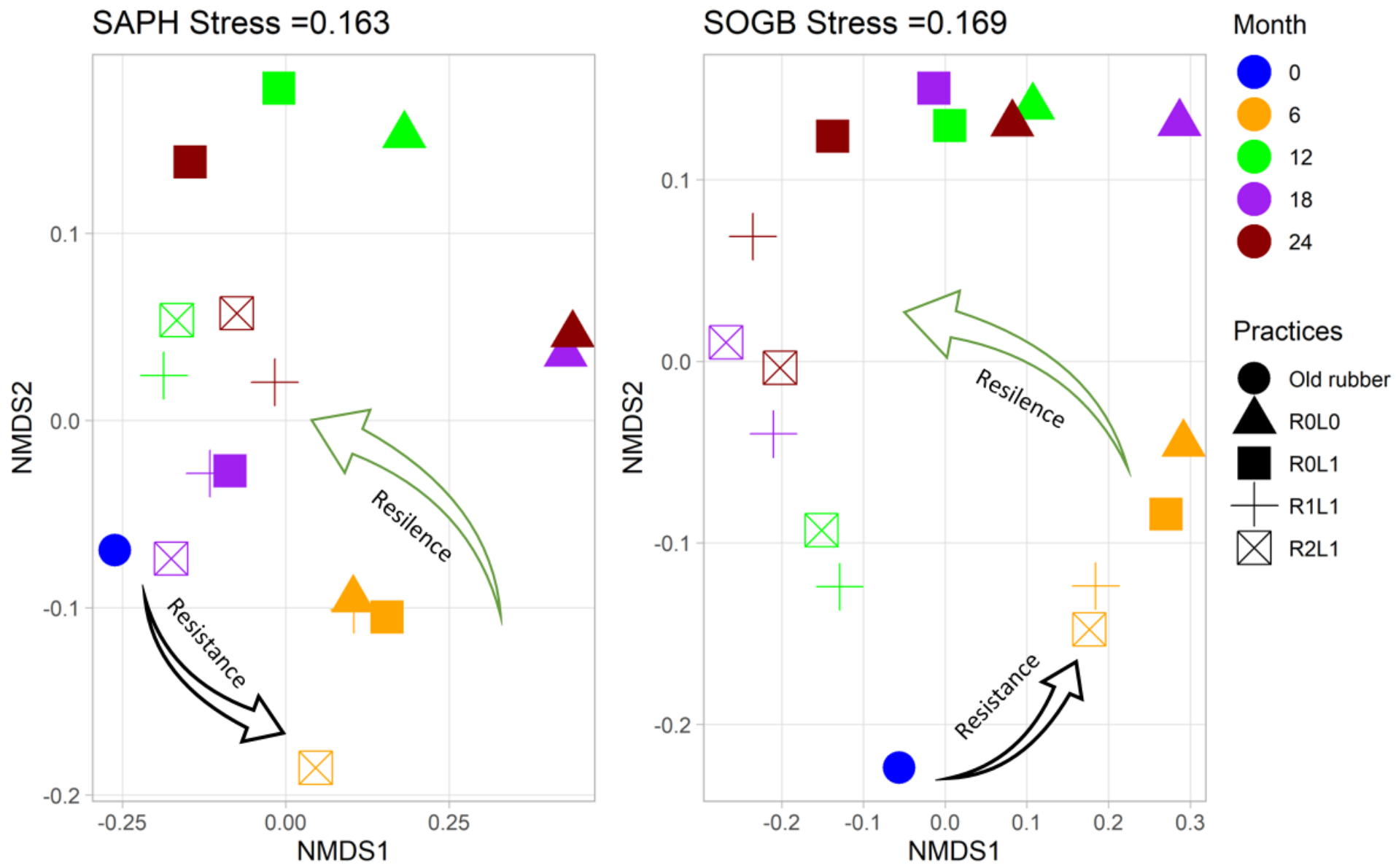

Figure 5

Non metric multidimensional scaling (NMDS) ordination based on Bray Curtis dissimilarity showing clustering of nematode communities among practices at both sites. SAPH, sandy site; SOGB, clay site; ROL0, no legumes or residues; ROL1, legume (Pueraria phaseoloides); R1L1, stump + leaf + fine branches; R2L1, R1L1+ trunk. Sampling points are grouped by type of practice type and by date. 

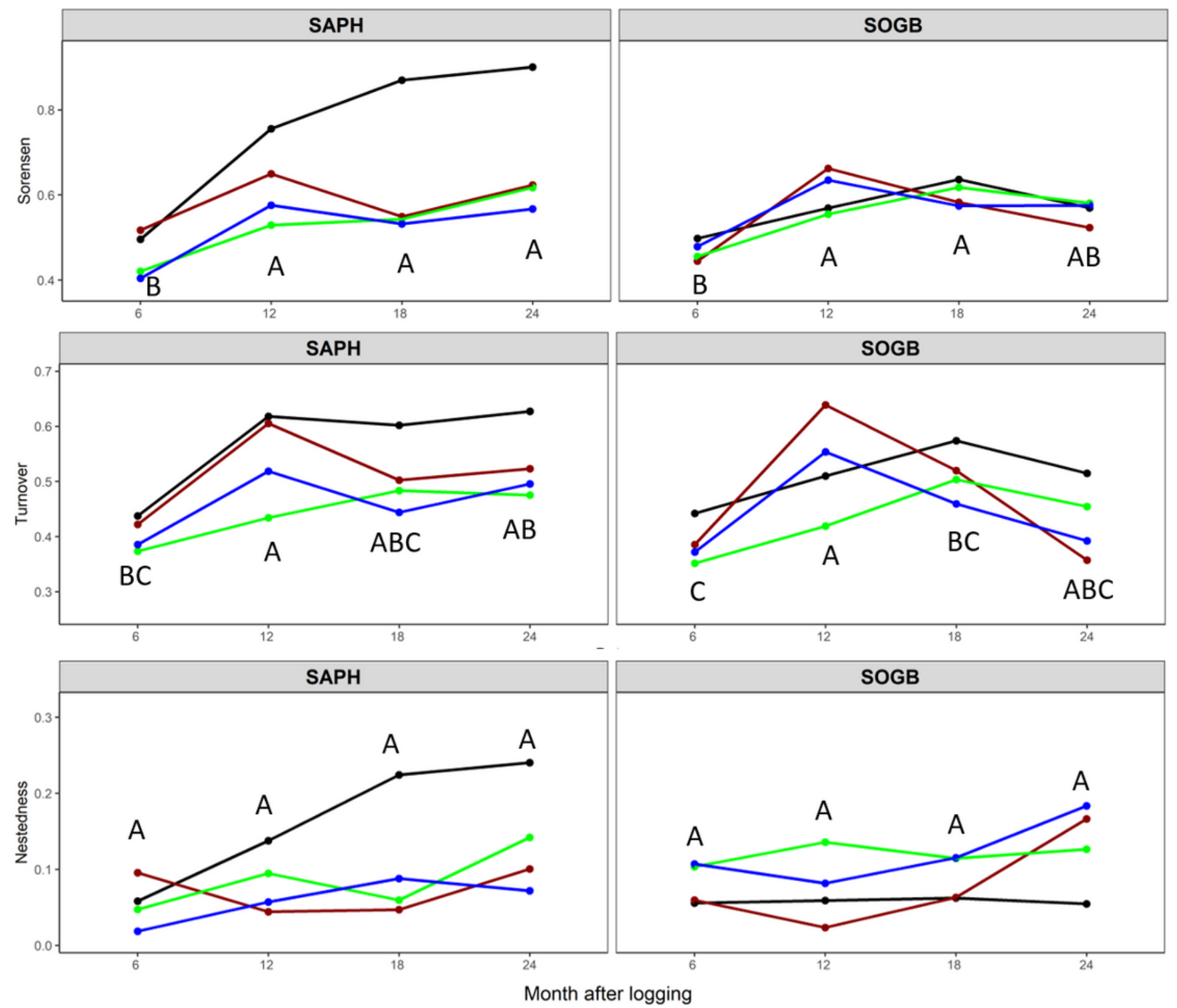

Figure 6

Global beta diversity of soil nematode composition and partitioning into nestedness and turnover components. The presence or absence data of taxa are used in this analysis. The different letters indicate the significant differences between sampling date according to Tukey's post hoc analysis. SAPH, sandy site; SOGB, clay site; ROL0, no legumes or residues; ROL1, legume (Pueraria phaseoloides); R1L1, stump + leaf + fine branches; R2L1, R1L1+ trunk.

\section{Supplementary Files}

This is a list of supplementary files associated with this preprint. Click to download.

- ArticleFigureSR.docx 
- ArticleTableSR.docx

- DataNematode.xlsx 